\title{
PREPARATION, STRUCTURE AND PROPERTIES OF COMPOUNDS CONTAINING THE DIPOSITIVE TRI-COPPER HEXA( $N, N$-DI- $n$-BUTYLDITHIOCARBAMATO) ION, COMPOUNDS WTTH COPPER IN THE OXIDATION STATES II AND III
}

\author{
BY \\ J. A. CRAS, J. WILLEMSE, \\ A. W. GAL and B. G. M, C. HUMMELINK-PETERS \\ (Laboratory for Inorganic Chemistry, University of Nijmegen, Toernooiveld, \\ Nijmegen)
}

The preparation, some magnetic, spectral and electrochemical properties of the compounds $\left.\left[\mathrm{Cu}_{3}\left(\mathrm{Bu}_{2} \mathrm{dtc}\right)_{6}\right]\left[\mathrm{MBr}_{3}\right]_{2} \mathrm{M}=\mathrm{Zn}, \mathrm{Cd}, \mathrm{Hg}\right)$ are reported. The crystal structure of the compound $\left[\mathrm{Cu}_{3}\left(\mathrm{Bu}_{2} \mathrm{dtc}\right)_{6}\right]\left[\mathrm{CdBr}_{3}\right]_{2}$ has been determined by a three-dimensional X-ray analysis. The triclinic cell, space group P1 with $\mathrm{a}=12.629(4), \quad \mathrm{b}=13.706(4), \quad \mathrm{c}=12.506(4) \quad \AA$ and $\quad \alpha=95.84(4)$. $\beta=91.45(4), \gamma=86.06(3)^{\circ}$, contains one formula unit. Atomic parameters were refined to a conventional $R$ value of 0.05 for 1344 independent non-zero reflections. The structure consists of two centrosymmetric ionic units $\left[\mathrm{Cu}_{3}\left(\mathrm{Bu}_{2} \mathrm{dtc}\right)_{6}\right]^{2+}$ and $\left[\mathrm{Cd}_{2} \mathrm{Br}_{6}\right]^{2-}$. In the cation one copper atom has an apically distorted octahedral S-coordination, with $\mathrm{Cu}-\mathrm{S}$ distances of 2.30(1), 2.35(1) and 3.19(1) $\AA$. The two other equivalent copper atoms have five-fold pyramidal S-coordinations with $\mathrm{Cu}-\mathrm{S}$ distances of 2.21(1), 2.22(1), 2.23(1), 2.23(1) and 2.88(1) $\AA$. The $\mathrm{Cd}_{2} \mathrm{Br}_{6}^{2-}$ ion can be described as a slightly-distorted edge-condensed bitetrahedron. Esr single-crystal spectra prove localisation of the unpaired electron at one copper atom. The I.R. spectra show double $\mathrm{Cu}-\mathrm{S}$ and C--N stretching frequencies. All these data suggest the compounds to be composed of copper in different states of oxidation. The cation can be described as $\left[\left(\mathrm{Cu}(\mathrm{III})\left(\mathrm{Bu}_{2} \mathrm{dtc}\right)_{2}\right)_{2} \mathrm{Cu}(\mathrm{II})\left(\mathrm{Bu}_{2} \mathrm{dtc}\right)_{2}\right]^{2+}$. The ionic structure is confirmed by conductivity measurements.

\section{Introduction}

Compounds with copper in a formal oxidation state of $+1 \frac{1}{2}$ are described in the literature ${ }^{1}$ mostly to have copper with equal, indistinguisable oxidation states. The best investigated example in this class of

1 H. M. McConnel and N. Davidson, J. Am. Chem. Soc. 72, 3168 (1950).

P. Day and D. W. Smith, J. Chem. Soc. A, 1045 (1967).

C. Sigward, P. Hemmerich and J. Spencer, Inorg. Chem. 7, 2545 (1968). 
compounds is the dark blue coloured solution, which is obtained when $\mathrm{Cu}\left(\mathrm{CH}_{3} \mathrm{CN}\right)_{4} \mathrm{ClO}_{4}$ is added to a solution of $\mathrm{Cu}\left(\mathrm{H}_{2} \mathrm{O}\right)_{6}\left(\mathrm{ClO}_{4}\right)_{2}$ in acetate-buffered methanol. Esr measurements on this solution at room temperature give a spectrum with seven hyperfine lines $(g=2.17$, $A=42 G$ ), indicating that the electron is localised equally on both copper atoms. Mixed valence states of copper atoms, however, are found in the compounds $\mathrm{Cu}_{3}\left(\mathrm{NH}_{3}\right)_{4}(\mathrm{CN})_{4}$ and $\mathrm{Cu}_{3}(\mathrm{en})_{2}(\mathrm{CN})_{4}{ }^{2}$. Spectral data of these compounds suggest that in the solid state as well as in highly concentrated solutions, association of $\left[\mathrm{Cu}\left(\mathrm{NH}_{3}\right)_{4}\right]^{2+}$ and $\left[\mathrm{Cu}(\mathrm{en})_{2}\right]^{2+}$ ions with species of copper in the oxidation state +1 exists.

In this publication we report a new series of mixed valence state compounds with copper in the formal oxidation state of $+2 \frac{2}{3}$ with general formula $\left[\mathrm{Cu}_{3}\left(\mathrm{Bu}_{2} \mathrm{dtc}\right)_{6}\right]\left[\mathrm{MBr}_{3}\right]_{2}(\mathrm{M}=\mathrm{Zn}, \mathrm{Cd}, \mathrm{Hg})$. They were obtained either by the reaction of $\mathrm{Cu}\left(\mathrm{bu}_{2} \mathrm{dtc}\right)_{2}, \mathrm{MBr}_{2}$ and $\mathrm{Br}_{2}$ in stoichiometric amounts or by the interaction of $3,5 \mathrm{bis}(N, N$-dialkyliminium)1,2,4-trithiolane tetrabromo-di- $\mu$-bromodicuprate(II), $\quad\left[\mathrm{Bu}_{4}\right.$ bitt $]$ $\left[\mathrm{Cu}_{2} \mathrm{Br}_{6}\right]^{3}$, and $\mathrm{M}\left(\mathrm{Bu}_{2} \mathrm{dtc}\right)_{2}$.

\section{Experimental Section}

The starting materials were obtained as described in the literature following the general procedure for the synthesis of dithiocarbamates ${ }^{4}$. The preparation of the following compounds is described in the references $\left(\mathrm{Bu}_{4} \mathrm{bitt}\right)^{2+}\left(\mathrm{Cu}_{2} \mathrm{Br}_{6}\right)^{2-3}, \mathrm{Cu}\left(\mathrm{Bu}_{2} \mathrm{dtc}\right) \mathrm{Br}_{2}{ }^{5}$.

Analyses. Heavy metals were analysed by atomic absorption photometric methods, using dilute aqua regia solutions as standards. The other elemental analyses were carried out in the micro-analytical department of this university.

Spectra. Infra-red spectra in the $4000-625 \mathrm{~cm}^{-1}$ region were measured on a PerkinElmer 257 infrared spectrophotometer. The spectra in the $700-200 \mathrm{~cm}^{-1}$ region were measured on a Hitachi-EPI-L instrument. All specimens were recorded in KBr pellets. $\mathrm{CsI}$ in the far infrared could not be used because of the oxidation of this compound with the $\left[\mathrm{Cu}\left(\mathrm{Bu}_{2} \mathrm{dtc}\right)_{2}\right]^{+}$complexes. Esr spectra were measured with a Varian V-4503 Q-band spectrometer.

The magnetic susceptibility was measured with a standard Gouy-type balance.

2 D. Cooper and R. Plane, Inorg. Chem. 5, 1677 (1967).

3 J. Willemse and J. A. Cras, Rec. Trav. Chim. 91, 1309 (1972).

${ }^{4}$ G. D. Thorn and $R$. A. Ludwig, "The dithiocarbamates and related compounds", Elsevier, Amsterdam (1962).

5 P. T. Beurskens, J. A. Cras and J. J. Steggerda, Inorg. Chem. 7, 810 (1968). 
Electrical conductivity measurements were performed with a Metrohm Konduktoskop E 365 and a Philips PR 9510/00 conductivity cell at $25^{\circ} \mathrm{C}$. Different standard solutions of $\mathrm{KCl}$ were used for calibration.

Equivalent conductivities were measured for $10^{-4}-5 \times 10^{-3} M$ solutions of the different compounds. The nitrobenzene was purified by freezing out and vacuum distillation.

\section{Preparation of the Complexes}

$\left[\mathrm{Cu}_{3}\left(\mathrm{Bu}_{2} \mathrm{dtc}\right)_{6}\right]\left[\mathrm{MBr}_{3}\right]_{2} \mathrm{M}=\mathrm{Zn}, \mathrm{Cd}, \mathrm{Hg}$.

To a suspension of $1 \mathrm{~mol}\left[\mathrm{Bu}_{4} \text { bitt }\right]^{2+}\left[\mathrm{Cu}_{2} \mathrm{Br}_{6}\right]^{2-}$ in chloroform a saturated solution of $2 \mathrm{~mol} \mathrm{M}\left(\mathrm{Bu}_{2} \mathrm{dtc}\right)_{2}$ in the same solvent was added. The former compound dissolved slowly and crystalline products could be obtained when petroleum ether $\left(40-60^{\circ} \mathrm{C}\right)$ was added to the solution and cooled at $0^{\circ} \mathrm{C}$. The compounds were dissolved in chloroform and recrystallized after addition of an equal amount of petroleum ether $\left(40-60^{\circ} \mathrm{C}\right)$.

$\left[\mathrm{Cu}\left(\mathrm{Bu}_{2} \mathrm{dtc}\right)_{2}\right]\left[\mathrm{MBr}_{3}\right] \mathrm{M}=\mathrm{Zn}, \mathrm{Cd}, \mathrm{Hg}$.

To a solution of $1 \mathrm{~mol} \mathrm{M}\left(\mathrm{Bu}_{2} \mathrm{dtc}\right)_{2}$ in chloroform a solution of $2 \mathrm{~mol} \mathrm{Cu}\left(\mathrm{bu}_{2} \mathrm{dtc}\right)_{2}$ in chloroform was added. After addition of an equal volume of petroleum ether $\left(40-60^{\circ} \mathrm{C}\right)$ crystalline products were obtained. They were filtered off and washed with petroleum ether $\left(40-60^{\circ} \mathrm{C}\right)$.

Once the composition of the products was known, a simpler route to these complexes suggested itself. A mixture of one mol of bromine in chloroform and two mol of $\mathbf{M B r}_{2}$ dissolved in ethanol was added with stirring to a solution of two or three mol of $\mathrm{Cu}\left(\mathrm{bu}_{2} \mathrm{dtc}\right)_{2}$ in chloroform. Upon addition of petroleum ether $\left(40-60^{\circ} \mathrm{C}\right)$ and cooling, precipitates of $\left[\mathrm{Cu}\left(\mathrm{Bu}_{2} \mathrm{dtc}\right)_{2}\right]\left[\mathrm{MBr}_{3}\right]$ or $\left[\mathrm{Cu}_{3}\left(\mathrm{Bu}_{2} \mathrm{dtc}\right)_{6}\right]\left[\mathrm{MBr}_{3}\right]_{2}$ respectively, were obtained*.

\section{Results and discussion}

\section{Magnetic data}

Magnetic susceptibility measurements were performed on the compound $\left[\mathrm{Cu}_{3}\left(\mathrm{Bu}_{2} \mathrm{dtc}\right)_{6}\right]\left[\mathrm{CdBr}_{3}\right]_{2}$ in the temperature range $100-293 \mathrm{~K}$. The Curie-Weiss law was followed with a $\Theta$-value of $-10 \mathrm{~K}$ and a molar paramagnetic susceptibility at $293 \mathrm{~K}$ of $1500 \times 10^{-6}$ c.g.s. units, corresponding with 1.8 B.M. Measurements on $\left[\mathrm{Cu}_{3}\left(\mathrm{Bu}_{2} \mathrm{dtc}\right)_{6}\right]$ $\left[\mathrm{MBr}_{3}\right]_{2}(\mathrm{M}=\mathrm{Zn}$ and $\mathrm{Hg})$ at $293 \mathrm{~K}$ gave the values of $\chi_{\mathrm{mol}}=1650 \times$ $10^{-6}$ and $1560 \times 10^{-6}$ c.g.s. units, respectively. These values correspond with one unpaired electron. The molar magnetic susceptibility of $\left[\mathrm{Cu}\left(\mathrm{Bu}_{2} \mathrm{dtc}\right)_{2}\right]\left[\mathrm{HgBr}_{3}\right]$ was found to be $-360 \times 10^{-6}$ c.g.s. units, which is very close to the sum of the diamagnetic susceptibilities of the constituent atoms $\left(-420 \times 10^{-6}\right.$ c.g.s. units $)$.

* Tables of the elemental analyses of the compounds investigated, as well as the atomic parameters, structure factors and bond angles and distances of the butyl chains of the compound $\left[\mathrm{Cu}_{3}\left(\mathrm{Bu}_{2} \mathrm{dtc}\right)_{6}\right]\left[\mathrm{Cd}_{2} \mathrm{Br}_{6}\right]$, are available on request. 
Esr spectra of the compounds $\left[\mathrm{Cu}_{3}\left(\mathrm{Bu}_{2} \mathrm{dtc}\right)_{6}\right]\left[\mathrm{MBr}_{3}\right]_{2}(\mathbf{M}=\mathrm{Zn}$, $\mathrm{Cd}, \mathrm{Hg}$ ) were measured at room temperature on powder samples as well as on solutions in chloroform. In the powder spectrum four equidistant lines could be observed on the low-field side, the high-field part of the spectrum was not resolved due to the broadness of the lines. Preliminary results $^{6}$ from single-crystal measurements at room temperature showed four broad lines in all directions. The derived principal g-values were $\mathrm{g}_{1}=2.0907(2), \mathrm{g}_{2}=2.0252(2), \mathrm{g}_{3}=2.0205(2)$ and the principal hyperfine values were $A_{z}=154.8(1), A_{y}=43.1(7)$ and $A_{x}=26.0(7) \times$ $10^{-4} \mathrm{~cm}^{-1}$. These values correspond well with those found by Weeks and Fackler $^{7}$ for a solid solution of monomeric $\mathrm{Cu}\left(\mathrm{Et}_{2} \mathrm{dtc}\right)_{2}$ in $\mathrm{Ni}\left(\mathrm{Et}_{2} \mathrm{dtc}\right)_{2}$ with principal g-values of $2.084(0.5), 2.025(1), 2.020(1)$ and principal A-values of 159(1), 42(2.5) and $36(2.5) \times 10^{-4} \mathrm{~cm}^{-1}$. Because of the broadness of the lines, only the low-field part of the powder spectrum, i.e. the part corresponding with the highest g-value, could be interpreted. The values of $g_{1}$ and $A_{z}$ determined from this part of the spectrum were in good agreement with those determined from the single-crystal spectra. Although in these compounds delocalisation of the unpaired electron at more than one copper atom would be expected, the principal values of $g$ and $A$ suggest the electron to be localised on one copper atom only.

Esr spectra of chloroform solutions are identical with those of $\mathrm{Cu}\left(\mathrm{Bu}_{2} \mathrm{dtc}\right)_{2}$ in chloroform.

\section{Infrared Spectra}

In Table I some absorption frequencies of the compounds are given. In the complexes $\left[\mathrm{Cu}\left(\mathrm{Bu}_{2} \mathrm{dtc}\right)_{2}\right]\left[\mathrm{MBr}_{3}\right](\mathrm{M}=\mathrm{Zn}, \mathrm{Cd}, \mathrm{Hg})$ the given absorption frequencies are about the same as those in $\mathrm{Cu}\left(\mathrm{Bu}_{2} \mathrm{dtc}\right)_{2} \mathrm{I}_{3}$. The increase in the $\mathrm{C}-\mathrm{N}$ stretching frequency of about $12 \mathrm{~cm}^{-1}$ is probably due to the effect of the anion the location of which has a distinct influence on the electron density on the nitrogen. The $\mathrm{I}_{3}^{-}$-anion is located at a van der Waals bonding distance ( $4 \AA$ ) from the nitrogen atom $^{9}$, so increasing the positive charge of this atom, which causes a higher $\mathrm{C}-\mathrm{N}$ bond order. The non-linear anions $\mathrm{MBr}_{3}^{-}$are not likely to be located at such a short distance from the nitrogen atom and do not have any effect on the $\mathrm{C}-\mathrm{N}$ bond order. The same effect is found in

${ }^{6}$ C. $P$. Keijzers, Private communication.

7 M. J. Weeks and J. P. Fackler, Inorg. Chem. '7, 2548 (1968).

8 H. C. Brinkhoff, Thesis, Nijmegen.

9 J. G. Wijnhoven, Th. E. M. v.d. Hark and P. T. Beurskens, J. Cryst. Mol. Struct. 2, 189 (1972). 
Table I

Some infrared absorption frequencies in $\mathrm{cm}^{-1}$ of $\left[\mathrm{Cu}_{3}\left(\mathrm{Bu}_{2} \mathrm{dtc}\right)_{6}\right]\left[\mathrm{MBr}_{3}\right]_{2}$ and $\left[\mathrm{Cu}\left(\mathrm{Bu}_{2} \mathrm{dtc}\right)_{2}\right]\left[\mathrm{MBr}_{3}\right]$

\begin{tabular}{|l|c|c|c|c|}
\hline & \multicolumn{2}{|c|}{$(\mathrm{C}-\mathrm{N})$} & \multicolumn{2}{c|}{ (Cu-S) } \\
\hline$\left[\mathrm{Cu}_{3}\left(\mathrm{Bu}_{2} \mathrm{dtc}\right)_{6}\right]\left[\mathrm{ZnBr}_{3}\right]_{2}$ & 1512 & 1548 & 362 & 398 \\
{$\left[\mathrm{Cu}_{3}\left(\mathrm{Bu}_{2} \mathrm{dtc}\right)_{6}\right]\left[\mathrm{CdBr}_{3}\right]_{2}$} & 1511 & 1548 & 360 & 397 \\
{$\left[\mathrm{Cu}_{3}\left(\mathrm{Bu}_{2} \mathrm{dtc}\right)_{6}\right]\left[\mathrm{HgBr}_{3}\right]_{2}$} & 1510 & 1549 & 360 & 397 \\
{$\left[\mathrm{Cu}\left(\mathrm{Bu}_{2} \mathrm{dtc}\right)_{2}\right]\left[\mathrm{ZnBr}_{3}\right]$} & & 1549 & & 408 \\
{$\left[\mathrm{Cu}\left(\mathrm{Bu}_{2} \mathrm{dtc}\right)_{2}\right]\left[\mathrm{CdBr}_{3}\right]$} & & 1551 & & 411 \\
{$\left[\mathrm{Cu}\left(\mathrm{Bu}_{2} \mathrm{dtc}\right)_{2}\right]\left[\mathrm{HgBr}_{3}\right]$} & & 1550 & & 404 \\
{$\left[\mathrm{Cu}\left(\mathrm{Bu}_{2} \mathrm{dtc}\right)_{2}\right] \mathrm{I}_{3}$} & & 1562 & & 411 \\
$\mathrm{Cu}\left(\mathrm{Bu}_{2} \mathrm{dtc}\right)_{2}$ & 1500 & & 352 & \\
\end{tabular}

the complexes $\left[\mathrm{Au}\left(\mathrm{R}_{2} \mathrm{dtc}\right)_{2}\right]^{+} \mathrm{X}^{-}$where $\mathrm{X}^{-}$stands for different anions ${ }^{10}$. Only one $\mathrm{Cu}-\mathrm{S}$ frequency is tentatively assigned.

Comparison of the infrared spectra of the compounds $\left[\mathrm{Cu}\left(\mathrm{Bu}_{2} \mathrm{dtc}\right)_{2}\right]$ $\left[\mathrm{MBr}_{3}\right]$ with those of the $\left[\mathrm{Cu}_{3}\left(\mathrm{Bu}_{2} \mathrm{dtc}\right)_{6}\right]^{2+}$-complexes shows the latter to have two strong absorption frequencies in the $1500-1550 \mathrm{~cm}^{-1}$ region, while two absorption peaks are present also in the $350-400 \mathrm{~cm}^{-1}$ region. The latter bands could arise from a $\mathrm{Cu}-\mathrm{S}$ stretching mode. $\mathrm{X}$-ray data show two different $\mathrm{Cu}$ sites to be present in these complexes, esr data indicate them to be $\mathrm{Cu}(\mathrm{II})$ and $\mathrm{Cu}(\mathrm{III})$. Given this it is reasonable to assign the lower of the $\mathbf{C}-\mathbf{N}$ stretching frequencies as belonging to the $\mathrm{Cu}(\mathrm{II})\left(\mathrm{Bu}_{2} \mathrm{dtc}\right)_{2}$ unit, the higher to the $\mathrm{Cu}(\mathrm{III})\left(\mathrm{Bu}_{2} \mathrm{dtc}\right)_{2}$ unit. In the same way the lowest $\mathrm{Cu}-\mathrm{S}$ frequency could belong to the $\mathrm{Cu}(\mathrm{II})$ unit, the highest to the $\mathrm{Cu}$ (III) moiety of the compounds.

The values show a slight increase in the $\mathrm{Cu}(\mathrm{II})-\mathrm{S}$ stretching frequency in the $\left[\mathrm{Cu}_{3}\left(\mathrm{Bu}_{2} \mathrm{dtc}\right)_{6}\right]\left[\mathrm{MBr}_{3}\right]_{2}$ complexes with respect to $\mathrm{Cu}$ (II)$\left(\mathrm{Bu}_{2} \mathrm{dtc}\right)_{2}$ and a slight decrease in the $\mathrm{Cu}(\mathrm{III})-\mathrm{S}$ frequency with respect to the $\mathrm{Cu}$ (III) complexes. This could indicate a decreased electron density on the $\mathrm{Cu}$ (II) atom and an increased electron density on the $\mathrm{Cu}$ (III) atoms, both leading to a too low effect to be seen in the bond length determined in the crystallographic studies. The effect however can also be ascribed to the difference in symmetry present in the $\left[\mathrm{Cu}_{3}\left(\mathrm{Bu}_{2} \mathrm{dtc}\right)_{6}\right]\left[\mathrm{MBr}_{3}\right]_{2}$ compounds and the compared $\mathrm{Cu}(\mathrm{II})$ and $\mathrm{Cu}$ (III) complexes.

Powdering a 2:1 mixture of $\left[\mathrm{Cu}\left(\mathrm{Bu}_{2} \mathrm{dtc}\right)_{2}\right]\left[\mathrm{MBr}_{3}\right]$ and $\mathrm{Cu}\left(\mathrm{Bu}_{2} \mathrm{dtc}\right)_{2}$ to obtain a summation spectrum, resulted in a solid state reaction, 
yielding the complex $\left[\mathrm{Cu}_{3}\left(\mathrm{Bu}_{2} \mathrm{dtc}\right)_{6}\right]\left[\mathrm{MBr}_{3}\right]_{2}$. Hence summation spectra had to be obtained by superposition of the separate spectra in the correct concentrations.

The metal-bromine frequencies are not observable above $200 \mathrm{~cm}^{-1}$ if the metal is cadmium or mercury. A fairly strong band is found at $241 \mathrm{~cm}^{-1}$ in the complexes containing $\mathrm{ZnBr}_{3}^{-}$. This absorption is much more intense than the absorptions found in the $230-250 \mathrm{~cm}^{-1}$ region of the cadmium and mercury complexes. So we tentatively assign this frequency to be a $\mathrm{Zn}-\mathrm{Br}$ stretching frequency.

\section{Conductivity Measurements}

The equivalent conductivities of the different compounds were measured in nitrobenzene. Following the procedure, described in a previous paper ${ }^{11}$, the concentration dependencies are expressed by the Onsager limiting law

$$
\Lambda=\Lambda_{\mathrm{o}}-\mathrm{A} \sqrt{\mathrm{c}}=\Lambda_{\mathrm{o}}-\left(\alpha_{\mathrm{o}}+\beta\right) \sqrt{\mathrm{c}}
$$

By plotting $\Lambda$ as a function of $\sqrt{\mathrm{c}}$ we found for the compounds under investigation the values for $\Lambda_{0}, A_{\text {exp }}$ and $A_{c a l c}$ as given in Table II.

Table II

Equivalent conductivities $\Lambda_{\mathrm{o}}$ in $\mathrm{cm}^{2} \Omega^{-1} \mathrm{eq}^{-1}$, and the experimental and calculated slopes $A_{\text {exp }}$ and $A_{c a l c}$ of the Onsager plot.

\begin{tabular}{|l|c|c|c|}
\hline & $\Lambda_{\mathrm{o}}$ & $\mathrm{A}_{\exp }$ & $\mathbf{A}_{\text {calc }}$ \\
\hline$\left[\mathrm{Cu}_{3}\left(\mathrm{Bu}_{2} \mathrm{dtc}\right)_{6}\right]\left[\mathrm{ZnBr}_{3}\right]_{2}$ & 24.9 & 66 & 63.5 \\
{$\left[\mathrm{Cu}_{3}\left(\mathrm{Bu}_{2} \mathrm{dtc}\right)_{6}\right]\left[\mathrm{CdBr}_{3}\right]_{2}$} & 30.2 & 127 & 139 \\
{$\left[\mathrm{Cu}_{3}\left(\mathrm{Bu}_{2} \mathrm{dtc}\right)_{6}\right]\left[\mathrm{HgBr}_{3}\right]_{2}$} & 28.7 & 75.8 & 67 \\
{$\left[\mathrm{Cu}\left(\mathrm{Bu}_{2} \mathrm{dtc}\right)_{2}\right]\left[\mathrm{HgBr}_{3}\right]$} & 28.1 & 75 & 66 \\
\hline
\end{tabular}

The value of $A_{\text {calc }}$ for $\left[\mathrm{Cu}_{3}\left(\mathrm{Bu}_{2} \mathrm{dtc}\right)_{6}\right]\left[\mathrm{CdBr}_{3}\right]_{2}$ was obtained assuming this complex to be a $1: 2$ electrolyte. The dimeric nature of the bromocadmate ion is confirmed by the X-ray structure determination of the compound. The experimental values of $\Lambda_{\mathrm{o}}$ and $\mathrm{A}_{\exp }$ for the compounds $\left[\mathrm{Cu}\left(\mathrm{Bu}_{2} \mathrm{dtc}\right)_{2}\right]\left[\mathrm{HgBr}_{3}\right],\left[\mathrm{Cu}_{3}\left(\mathrm{Bu}_{2} \mathrm{dtc}\right)_{6}\right]\left[\mathrm{ZnBr}_{3}\right]_{2}$ and $\left[\mathrm{Cu}_{3}\left(\mathrm{Bu}_{2} \mathrm{dtc}\right)_{6}\right]$ $\left[\mathrm{HgBr}_{3}\right]_{2}$, are normal for $1: 1$ electrolytes. So the conclusion can be

11 P. T. Beurskens, H. J. A. Blaauw, J. A. Cras and J. J. Steggerda, Inorg. Chem. 7, 805 (1968). 
drawn that in nitrobenzene the former compound is fully dissociated into the ions $\mathrm{Cu}\left(\mathrm{Bu}_{2} \mathrm{dtc}\right)_{2}^{+}$and $\mathrm{HgBr}_{3}^{-}$, the latter complexes in a neutral $\mathrm{Cu}\left(\mathrm{Bu}_{2} \mathrm{dtc}\right)_{2}$ molecule, two $\mathrm{Cu}\left(\mathrm{Bu}_{2} \mathrm{dtc}\right)_{2}^{+}$ions and two $\mathrm{MBr}_{3}^{-}(\mathrm{M}=\mathrm{Zn}$, $\mathrm{Hg}$ ) ions.

\section{Crystal data}

The compound $\operatorname{bis}[\operatorname{bis}(N, N$-di- $n$-butyldithiocarbamato)copper(III)] bis $(N, N$-di-n-butyldithiocarbamato)copper(II)tetrabromo-di- $\mu$-bromo dicadmate(II), F.W. 2121.13 crystallizes as dark violet-black needles. Weissenberg photographs showed the crystals to be triclinic. From platinum calibrated Weissenberg photographs, using $\mathrm{CuK} \alpha$ radiation $(\lambda=1.5418 \AA)$ application of a least-squares procedure yielded the unit cell dimensions $a=12.629(4), b=13.706(4), c=12.506(4) \AA$; $\alpha=95.84(4), \beta=91.45(4), \gamma=86.03^{\circ}$ and $V=2148.0(5) \AA^{3}$. The density $D_{M}=1.6346 \mathrm{gcm}^{-3}$ was determined by the flotation method. The calculated density, $D_{X}$, is $1.6404 \mathrm{gcm}^{-3}$ with $Z=1$.

A crystal of approximate diménsions $0.07 \times 0.07 \times 0.2 \mathrm{~mm}^{3}$ was mounted with needle axis (110) along the $\phi$-axis of a Nonius automatic diffractometer. Intensity data were measured with $\mathrm{Zr}$-filtered Moradiation using the moving-counter moving-crystal method with a scan speed of $1.2^{\circ} \mathrm{min}^{-1}$. After every 14 reflections a reference reflection was measured to allow corrections to be made for fluctuations in the measuring performance.

Of the 4000 independent reflections theoretically attainable within the limit $\Theta=20^{\circ}, 1344$ reflections were used for the structure determination.

Absorption corrections (linear absorption coefficient $\mu=45.0$, maximum influence 1.34 , minimum influence 1.30 in the intensities) were calculated by the Busing and Levy ${ }^{12}$ procedure using $4 \times 4 \times 10$ volume components and 10 accurately located boundary planes. Lorentz and polarisation corrections were performed in the usual way, and the presumed standard deviations $\sigma\left(\mathrm{F}_{\mathrm{o}}\right)$ of the structure amplitudes were derived from $\sigma(\mathrm{I})=\sigma_{\mathbf{C}}$, where $\sigma_{\mathrm{C}}$ is the counting statistical error.

\section{Structure Determination}

The positions of the cadmium, bromine and copper atoms were determined from a three-dimensional Patterson function. Two subsequent 
difference Fourier syntheses, assuming the structure to be centrosymmetric, gave the positions of the remaining non-hydrogen atoms. The positional and vibrational parameters were refined in two diagonal blocks in alternating cycles. The first block contained the positional and the anisotropic temperature parameters of cadmium, bromine, copper and sulfur, and the scaling factor, the second block the positional and isotropic vibrational parameters of nitrogen and carbon and the scaling factor. The function that was minimized was $\Sigma w\left(\left|\mathrm{~F}_{\mathrm{o}}\right|-\left|\mathrm{F}_{\mathrm{c}}\right|\right)^{2}$ with weight $w=\left(\sigma^{2}\left(\mathrm{~F}_{\mathrm{o}}\right)+\left(0.05\left|\mathrm{~F}_{\mathrm{o}}\right|\right)^{2}\right)^{-113}$. The atomie scattering factors were those of $\mathrm{Cd}, \mathrm{Br}^{-}, \mathrm{Cu}$ for $\mathrm{Cu}(\mathrm{II})$ and $\mathrm{Cu}^{+}$for $\mathrm{Cu}$ (III), $\mathrm{S}$, $\mathrm{N}$ and $\mathrm{C}$ corrected for the anomalous scattering component $\left(\Delta \mathrm{f}^{\prime}\right)$ using data from the International Tables ${ }^{14}$. The final $\mathrm{R}$-value was 0.05 for the 1344 observed reflections.

\section{Description of the Structure}

The structure is illustrated in Fig. 1. Bond angles and distances of the important atoms are given in Fig. 2 .

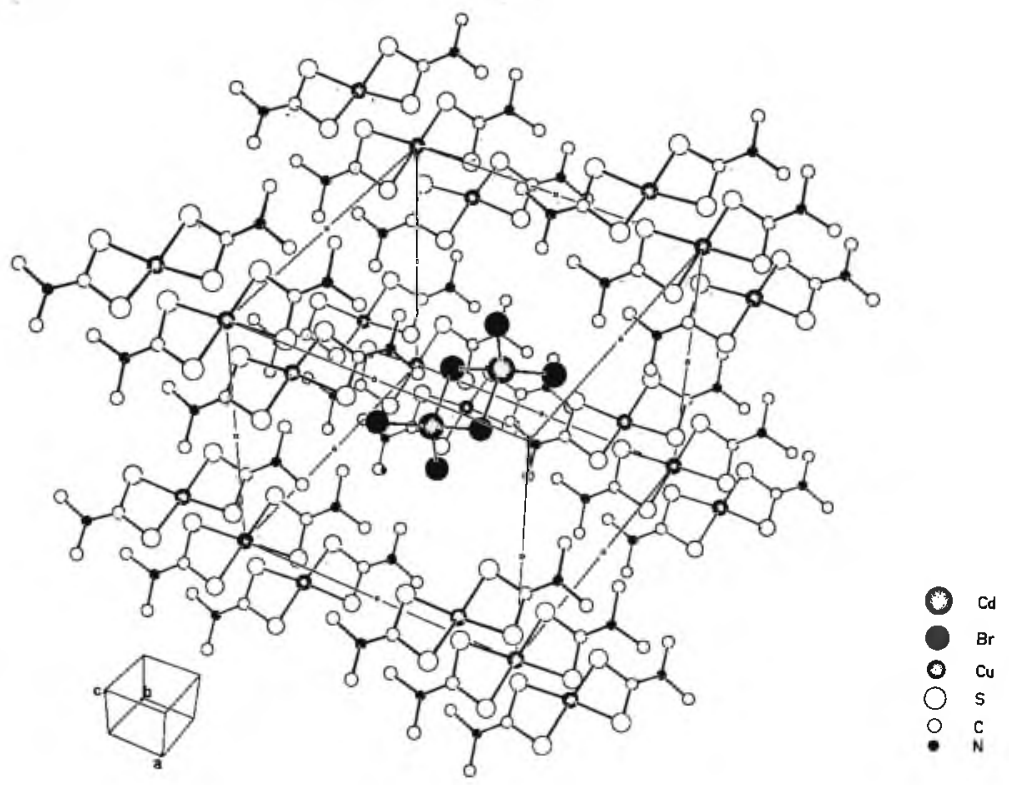

Fig. 1 .

13 J. G. Wijnhoven, W. P. J. H. Bosman and P. T. Beurskens, J. Cryst. Mol. Struct. 2, 7 (1972).

${ }^{14}$ International Tables for X-Ray Crystallography III (1962). 


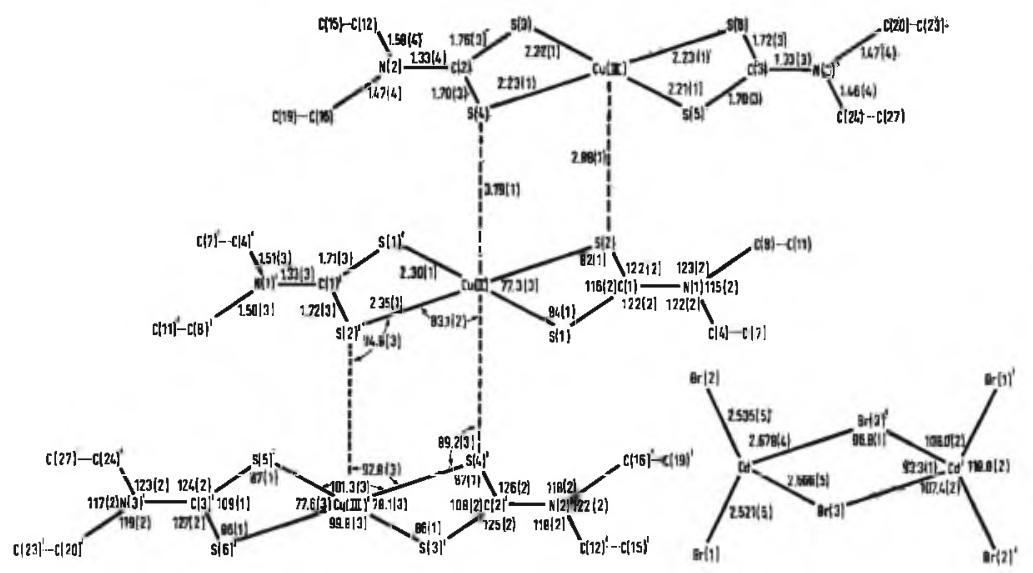

Fig. 2.

The crystal structure analysis revealed the compound to be composed of two centrosymmetric ions $\left[\mathrm{Cu}_{3}\left(\mathrm{Bu}_{2} \mathrm{dtc}\right)_{6}\right]^{2+}$ and $\left[\mathrm{Cd}_{2} \mathrm{Br}_{6}\right]^{2-}$. The cation contains three $\mathrm{Cu}\left(\mathrm{Bu}_{2} \mathrm{dtc}\right)_{2}$ units. One of these units is planar centrosymmetric with $\mathrm{Cu}-\mathrm{S}$ distances which are not significantly different from those in $\mathrm{Cu}\left(\mathrm{Et}_{2} \mathrm{dtc}\right)_{2} 2.317(2), 2.297(2), 2.301(2)$ and 2.339(2) $\AA^{15}$. The other two equivalent $\mathrm{Cu}\left(\mathrm{Bu}_{2} \mathrm{dtc}\right)_{2}$ units are slightly pyramidally deformed planes with much shorter $\mathrm{Cu}-\mathrm{S}$ distances, which are the same as those in $\left[\mathrm{Cu}\left(\mathrm{Bu}_{2} \mathrm{dtc}\right)_{2}\right]^{+} \mathrm{I}_{3}^{-} 2.23(2), 2.22(2), 2.21(2)$ and $2.22(2)^{9}$. From these data it is justifiable to conclude that in the first unit copper has the formal oxidation state +2 and in the second unit it has the formal oxidation state +3 .

The three units are piled at remarkably short distances: $\mathrm{Cu}(\mathrm{III})-\mathrm{S}$ $2.88 \AA$ and $\mathrm{Cu}(\mathrm{II})-\mathrm{S} 3.19 \AA$. Therefore the coordination of $\mathrm{Cu}(\mathrm{III})$ can be described as distorted square pyramidal and that of $\mathrm{Cu}(\mathrm{II})$ as distorted octahedral. The structure of the complex cation can be compared with that of nickel dithiobenzoate ${ }^{16}$ in which three units are also stacked in a B-A-B order. The B-type unit in that compound also seems to have a deviation of planarity, although the deviations are not given by the authors. The $\mathrm{Cu}$ atom in the B-type unit of our compound has a deviation of the least-squares plane, defined by the atoms $S_{3} S_{4} S_{5} S_{6}$,

15 M. Bonamico, G. Dessy, A. Zambonelli, A. Mugnoli and A. Vaciago, Acta Cryst. 19, 886 (1965).

16 M. Bonamico, G. Dessy and V. Fares, Chem. Comm. 324 (1969). 
of $0.266(4) \AA$. The pyramidal coordination of this $\mathrm{Cu}(\mathrm{III})$ is noteworthy for a $d^{8}$ configuration. The structure of the anion is comparable with that of the $\mathrm{Hg}_{2} \mathrm{I}_{6}^{2-}$ ion in the complex $\left[\mathrm{Et}_{4} \mathrm{bitt}\right]^{2+}\left[\mathrm{Hg}_{2} \mathrm{I}_{6}\right]^{2-}{ }^{17}$ and can be described as a slightly-distorted edge-condensed bitetrahedron. All interionic contacts are in the expected range.

\section{Acknowledgements}

The authors are grateful to Professor $J$. J. Steggerda for his interest in this work, to Dr. J. H. Noordik for measuring the X-ray intensities, to Drs. C. $P$. Keijzers for recording the esr spectra and for valuable discussions and to Mr. J.M.M. Smits for technical assistance.

(Received October 3rd, 1972)

17 P. T. Beurskens, W. P.J. H. Bosman and J. A. Cras, J. Cryst. Mol. Struct. 2, 183 (1972). 
4 